\title{
IMPLEMENTASI SISTEM AKUNTANSI INSTANSI BERBASIS AKRUAL (SAIBA) PADA BALAI DIKLAT KEAGAMAAN PROVINSI ACEH
}

\author{
Andi 'Kasfari*1', Syukriy Abdullah ${ }^{* 2}$ \\ ${ }^{1,2}$ Program Studi Akuntansi Fakultas Ekonomi dan Bisnis Universitas Syiah Kuala \\ e-mail: andikasfari22@gmail.com ${ }^{* 1}$, syukriyabdullah@feb.unsyiah.ac.id ${ }^{* 2}$
}

\begin{abstract}
Abstrak
The purpose of this study provides a description of the impact and challenges in the implementation of the AccrualBased Agency Accounting System (SAIBA). This research was conducted at the Religious Training Center in the Province of Aceh. Type of qualitative research with data collection based on interview techniques, observation and documentation studies. Data is obtained by going down directly to the research location and reviewing it with existing literature studies. This research is expected to be useful for the staff of the Aceh Province Religious Training Center in implementing accrual-based accounting to run optimally. The results show that the Implementation of Accrual-Based Agency Accounting System at the Center for Religious Training in Aceh Province has not been so effective. The problem is related to the readiness of human resources who have not fully understood accrual-based accounting. However, the implementation of accrual-based accounting has brought significant benefits. Challenges in the implementation of accrual-based accounting in terms of leadership commitment, the Aceh Province Religious Training Center supports changes in accrual-based accounting because clear and absolute regulations regarding systems, procedures, and policies are regulated in PP 71 of 2010. Accounting systems and IT facilities and infrastructure have been adequate. As a form of anticipation of the emergence of staff resistance, the strategy carried out in the form of socialization as well as training was intensified in early 2015 but there was a decline in the following year. Resistance appears on two considerations, namely the ease and benefits of implementing SAIBA. The response of the staff of the Aceh Province Religious Training Center is that it is easy to run the SAIBA application for those who have mastered and can facilitate staff performance. On the other hand, there are benefits obtained from the SAIBA application as financial reports are more transparent and accurate.
\end{abstract}

Keywords: Accrual-Based Agency Accounting System, Technology Acceptance Model concept.

\section{Pendahuluan}

Implementasi akuntansi pemerintahan daerah diawali pada tahun 2007 setelah diterbitkan Peraturan Pemerintah Nomor 24 Tahun 2005 Tentang Standar Akuntansi Pemerintahdan Peraturan Menteri Dalam Negeri Nomor 13 Tahun 2006 Tentang Pedoman Pengelolaan Keuangan Daerah. Serta diperkuat dengan Peraturan Pemerintah Nomor 56 Tahun 2005 Tentang Sistem Akuntansi Keuangan Daerah menyatakan dalam mengelola keuangan daerah maka setiap pemerintah berkewajiban untuk memanfaatkan teknologi yang ada guna meningkatkan keuangan daerah dan mendistribusikannya untuk pelayanan publik.

Saputra (2015) menyatakan sehubungan dengan peningkatan tata kelola keuangan yang ditandai dengan amanat Undang-Undang Nomor 17 Tahun
2003 Tentang Keuangan Negara, Undang-Undang Nomor 1 Tahun 2004 Tentang Perbendaharaan Negara dan Undang-Undang Nomor 15 Tahun 2004 Tentang Pemeriksaan Pengelolaan dan Tanggung Jawab Keuangan Negara, mewajibkan semua instansi pemerintah diseluruh indonesia menerapkan akuntansi berbasis akrual mulai tahun 2008 yakni lima tahun setelah undang-undang tersebut ditetapkan. Namun, implementasi berbasis akrual baru bisa dilaksanakan secara penuh ditahun 2015, yakni setelah diterbitkannya Peraturan Pemerintah Nomor 71 Tahun 2010 Tentang Standar Akuntansi Pemerintahan yang ditindaklanjuti oleh Peraturan Menteri Dalam Negeri Nomor 64 Tahun 2013 Tentang Penerapan Standar Akuntansi Pemerintah Berbasis Akrual pada Pemerintah Daerah.

Peraturan Menteri Keuangan Nomor 
213/PMK.05/2013 Tentang Sistem Akuntansi dan Pelaporan Keuangan Pemerintah Pusat menyatakan Sistem Akuntansi Pemerintah Pusat (SAPP) mempunyai subsistem yang terdiri atas Sistem Akuntansi Bendahara Umum Negara (SABUN) dan Sistem Akuntansi Instansi (SAI). Adapun mengenai Sistem akuntansi Instansi berbasis Akrual merupakan perkembangan terbaru dari SAI.

Dalam rangka penerapan akuntansi berbasis akrual tahun 2015 di pemerintah pusat, ketentuan mengenai aplikasi Sistem Akuntansi Instansi Berbasis Akrual (SAIBA) berpedoman pada Peraturan Menteri Keuangan Nomor 270/PMK.05/2014 Tentang Penerapan Standar Akuntansi Pemerintahan Berbasis Akrual pada Pemerintah Pusat menyatakan pada pasal 3 ayat (1) penerapan SAP berbasis akrual sebagaimana dimaksud dalam pasal 2 dilaksanakan menggunakan aplikasi Terintegrasi. Akan tetapi pada pada pasal 5 ayat (1)dalam hal sistem aplikasi terintegrasi sebagaimana dimaksud dalam pasal 3 ayat (3) belum dapat dilaksanakan, laporan keuangan berbasis akrual disusun menggunakan aplikasi SAIBA. Demikian hal ini juga berlaku di Kementerian Agama Republik Indonesia.

Implementasi Akuntansi Pemerintah Berbasis Akrual (APBA) sudah resmi dijalankan dalam jajaran Kementerian Agama yang ditandai dengan login SAIBA oleh Menteri Agama. Sejalan dengan peningkatan efektifitas, transaparansi dan akuntabilitas laporan keuangan Kementerian Agama. Menteri Agama melakukan langkah kesiapan untuk menerapkan akuntansi berbasis akrual diantaranya dengan penyesuaian regulasi dibidang akuntansi dan pelaporan keuangan seperti penerapan standar berbasis akrual pada Kementerian Agama, pembangunan sistem aplikasi, peningkatan kapasitas sumber daya manusia serta penguatan komitmen pimpinan satuan kerja (kemenag.go.id, 27 Maret 2015).

Keputusan Menteri Agama Nomor 15 Tahun 2015 Tentang Penerapan Standar dan Sistem Akuntansi Pemerintahan Berbasis Akrual pada Kementerian Agama menetapkan penyajian laporan keuangan kementerian agama (LKKA) berdasarkan akuntansi berbasis kas dan akrual. Penggunaan akuntansi berbasis kas untuk penyusunan Laporan Realisasi Anggaran (LRA) sedangkan akuntansi berbasis akrual digunakan dalam penyusunan Laporan Operasional (LO), Laporan Perubahan Ekuitas (LPE) dan Neraca. Sistem Akuntansi Kementerian Agama (SAKA) merupakan metode dalam siklus akuntansi yang dijanlankan oleh unit akuntansi dengan tata cara pelaksanaan pemrosesan transaksi keuangan maupun barang dalam menghasilkan laporan keuangan yang bermamfaat. pelaksanaan SAIBA juga diwajibkan pada Satuan Kerja Balai Diklat Keagamaan Provinsi Aceh sebagai salah satu unit akuntansi Kementerian Agama.

Balai Diklat Keagamaan Provinsi Aceh sudah menerapkan basis akrual ditahun 2015 mengacu pada Peraturan Pemerintah 71 tahun 2010 Tentang Standar Akuntansi Pemerintah. Pada awal penerapan terdapat beberapa kendala seperti kekurangan analis sistem yang mampu membaca setiap proses alur bisnis dari SAIBA. Kendala lain dipicu dari minimnya dasar akuntansi yang dimiliki oleh setiap karyawan dikarenakan kurangnya lulusan akuntansi di Balai Diklat Keagamaan Provinsi Aceh.Dalam rangka mempercepat impelemtansi SAIBA pada Balai Diklat Keagamaan Provinsi Aceh, maka telah melakukan strategi dengan cara membuat pelatihan-pelatihan untuk karyawan yang berhubungan lansung dengan aplikasi SAIBA serta bimbingan teknis pengelolaan SAIBA.

Pada proses perkembangannya, penerapan laporan keuangan akuntansi akrual dipemerintah daerah mengalami beberapa hambatan. Permasalahan tersebut muncul karena masih dalam transisi berbasis kas seperti resistensi dari karyawan, kekurangan sumber daya manusia yang berkompeten, juga ada beberapa daerah yang tidak memiliki sarana dan prasarana penunjang pengauditan seperti audit elektroniks, aspek budaya organsisasi dan lingkungan (kompasiana.com, 15 Mei 2016).

Penelitian mengenai Sistem Akuntansi Instansi Berbasis Akrual ini telah banyak dilakukan sebelumnya antara lain penelitian oleh Mehrolhassani (2014), Hasil penelitian menunjukkan bahwa pembentukan sistem akuntansi basis akrual menghadapi tantangan insfrastruktur, terutama komponen kepemimpinan, manajemen dan pengikut. selanjutnya, hasil penelitian Azmi (2014) menunjukkan bahwa karyawan akuntansi siap untuk menerapkan akuntansi akrual dan bersedia untuk pindah ke akuntansi akrual. Berbanding terbalik dari penelitian lainnya,

Penelitian mengenai Sistem Akuntansi Instansi 
Berbasis Akrual (SAIBA) ini juga telah banyak dilakukan pada beberapa instansi dan organisasi pemerintahan di Indonesia. Antara lain penelitian Sari (2017) yang menyimpulkan bahwa RSUD Kardinah telah siap dalam melaksanakan SAP berbasis akrual yang dilihat dari beberapa parameter mengenai penerapan basis akrual. Hal senada juga dipaparkan dalam penelitian Herwiyanti (2017) menyimpulkan Kesiapan Itjen Kemenkeu dalam Menerapkan system akuntansi akrual sudah baik, mulai dari aspek komunikasi sumber daya, komitmen organisasi dan struktur birokrasi. Kemudian penelitian Kurniawan (2016) menyimpulkan bahwa implementasi program sistem informasi akuntansi berbasis akrual sesuai dengan standar akuntansi pemerintahan.

Adapun Zawitri (2015) menyatakan rekontruksi laporan keuangan politeknik negeri Pontianak sesuai dengan system akuntansi berbasis akrual sebagai bentuk implementasi PP 71 Tahun 2010 dengan penambahan laporan operasional dan laporan perubahan ekuitas. Sedangkan hasil penelitian Rosalia (2017) menunjukkan bahwa determinan terhadap penerapan laporan keuangan berbasis akrual di universitas Perguruan Tinggi Negeri (PTN) Badan Hukum (BH) adalah system berbasis Teknolog informasi (TI), sumber daya manusia kompeten, komitmen dari pemimpin, resistensi, lingkungan dan kebijakan internal. Diikuti oleh hasil penelitian Noviyanti (2016), menunjukkan bila pengguna memiliki persepsi penggunaan system informasi dapat memberikan manfaat mempercepat penyelesaian pekerjaan, meningkatkan kinerja, meningkatkan produktivitas, dan efisiensi pekerjaan, maka kepuasan atas penggunaan system informasi tersebut semakin tinggi.

Penelitian ini merupakan modifikasian penelitian-penelitian terdahulu tentang implementasi sistem akuntansi instansi berbasis akrual. Berdasarkan penelitian sebelumnya, penulis berkeinginan untuk melakukan pengembangan lebih lanjut terkait dengan penelitian tersebut. Terdapat beberapa perbedaan mendasar dalam penelitian.pada penelitian ini, pengukuran kesiapan sistem akuntansi instansi berbasis akrual dengan menggunakan Technology Acceptance Model (TAM), yang tidak digunakan pada pemaparan penelitian terdahulu.

Perbedaan lainnya terletak pada objek penelitian, objek pada penelitian ini ialah satuan kerja
Balai Diklat Keagamaan Provinsi Aceh sedangkan pada penelitian sebelumnya melakukan penelitian pada Kementerian Keuangan, rumah sakit dan objek yang lebih luas seperti Inspektorat Jenderal Pajak. Selanjutnya jika pada penelitian sebelumnya melakukan studi penelitian diluar Aceh, maka pada penelitian ini di Provinsi Aceh.

Adapun tujuan yang ingin dicapai dalam penelitian ini yaitu:

1. Untuk mengetahui pelaksanaan Sistem Akuntansi Instansi Berbasis Akrual pada Balai Diklat Keagamaan Provinsi Aceh

2. Untuk mengetahui bagaimana dampak dari Implementasi Sistem Akuntansi Instansi pada Balai Diklat Keagamaan Provinsi Aceh

3. Untuk mengetahui peluang dan tantangan dalam Implementasi Sistem Akuntansi Instansi Berbasis Akrual pada Balai Diklat Keagamaan Provinsi Aceh

\section{Kajian Pustaka}

\section{StandarAkuntansi Pemerintahan di Indonesia}

Fase perkembangan akuntansi pemerintahan di Indonesia sudah dimulai dari awal Tahun 1975 hingga berakhir dengan Peraturan Pemerintah Nomor 71 Tahun 2010 (Priyono, 2012). Permasalahan timbul pada tahun 1970-an karena ketidakharmonisan antara departemen keuangan dengan departemen dalam negeri dalam menentukan standar mana yang digunakan sebagai patokan dalam penyusunan laporan keuangan pemerintah (Soepomo, 1999 dalam Harun, 2009:146). Pembuatan standar akuntansi pemerintah pada masa itu hanyalah sebatas wacana.

Dampak baik dari penerapan Standar Akuntansi Pemerintah (SAP) merupakan sarana pengukuran dan perbandingan antar laporan keuangan sehingga pencegahan terhadap praktik Korupsi, Kolusi dan Nepotisme (KKN) dapat dihindarkan dalam proses keuangan negara dan daerah. Oleh karena hal itu, SAP merupakan alat atau media guna memfasilitasi laporan keuangan menjadi transparan dan akuntabel.

Nordiawan \& Hertianti (2010:9) mendefinisikan standar akuntansi sebagai Prinsip Akuntansi Berlaku Umun (PABU). PABU merupakan hirarki ketentuan yang mengatur mengenai perlakuan akuntansi yang dapat dijadikan sebagai bahan acuan dalam pencatatan suatu transaksi. Penyusunan Standar Akuntansi Pemerintahdi bentuk oleh Komite Standar Akuntansi 
Pemerintah (KSAP). KSAP terdiri dari Komite Konsultatif bertugas memberi konsultasi atau pendapat mengenai perumusan SAP dan Komite Kerja berkemampuan dalam merumuskan dan menyusun konsep SAP (Forum Dosen Akuntansi Sektor Publik, 2006:5). Ada beberapa basis akuntansi yang digunakan dalam menentukan pengakuan pencatatan diantaranya

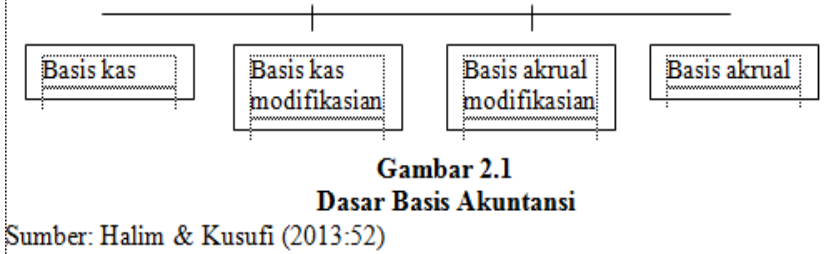

\section{Sistem Akuntansi Instansi Berbasis Akrual Berdasarkan Peraturan Pemerintah Nomor 71 Tahun 2010}

Peraturan Pemerintah Nomor 71 tahun 2010 menjelaskan SAP basis akrual adalah "SAP yang mengakui pendapatan, beban, aset, utang dan ekuitas dalam pelaporan finansial berbasis akrual serta mengakui pendapatan, belanja dan pembiayaan dalam pelaporan pelaksanaan anggaran berdasarkan basis yang ditetapkan dalam APBN/APBD".

Konsep dalam basis akrual didasari pada dua pilar yakni pengakuan terhadap pendapatan dan pengakuan biaya atau beban. Basis akrual mengakui pendapatan pada saat pemerintah mempunyai wewenang untuk melakukan penagihan dari hasil kegiatan yang dilakukan pemerintah. Dalam pemahaman konsep akrual, pernyataan kapan kas benar-benar diterima menjadi hal yang tidak begitu penting. Oleh sebab itu, kemudian terdapat kemunculan estimasi piutang tak tertagih dikarenakan kas belum diterima tetapi penghasilan sudah diakui. Sedangkan untuk pengakuan dianggapnya suatu biaya atau beban ketika kewajiban membayar sudah terjadi meskipun biaya tersebut belum dibayar (Zawitri, Kurniasih \& Kartikawati (2015).

Adapun kesimpulan terhadap pelaksanaan akuntansi berbasis akrual untuk memperbaiki basis kas yang tidak berkecukupan dalam memberikan data yang lebih akurat. Sebagai bentuk dukungan pelaksanaan akuntansi berbasis akrual dipemerintah pusat, langkah cerdas yang dilakukan Direktorat Jenderal Perbendaharaan dengan cara melakukan pengembangan aplikasi SAI (SAKPA dan SIMAKBMN) menjadi SAIBA. Pengembangan tersebut terlihat pada proses modifikasian dari sebelumnya aplikasi Sistem Akuntansi Kuasa Pengguna Anggaran (SAKPA) menjadi aplikasi SAIBA (Modul Proses bisnis SAIBA, 2014)

\section{Kesiapan pengguna dalam penerapan Sistem Akuntansi Instansi Berbasis Akrual berdasarkan Teori Technology Acceptance Model (TAM)}

Salah satu titik permasalahan dalam perubahan basis terletak pada ketidaksiapan pengguna untuk menerima perubahan serta berkeinginan menjalankan system baru. Apalagi penerapan basis akrual akan membuat banyak perubahan dan perbedaan dari segi prosedur (Ichsan 2013 dalam Najati et al., 2016).

Ada beberapa model dalam penerimaan suatu teknologi informasi baru, salah satunya model yang dikembangkan oleh Davis padatahun 1989 yaituTechnology Acceptance Model (TAM).Lestari (2017) menyatakan bahwa TAM sebagai salah satu model untuk mengetahui faktor-faktor yang dapat memberikan pengaruh dalam penerimaan (acceptance) atau pemahaman operator/analis terhadap implementasi aplikasi SAIBA.

Siregar(2011) menyatakan ada dua pertimbangan yang dapat mempengaruhi kemauan terhadap adopsi teknologi informasi diantaranya persepsi terhadap tingkat kemudahan dalam menggunakan teknologi dan persepsi akan mamfaat dari teknologi tersebut.

\section{Metode Penelitian \\ Desain Penelitian}

Desain penelitian merupakan suatu perencanaan dalam mengumpulkan, mengukur dan menganalisis data berdasarkan pertanyaan penelitian.Penelitian ini berjenis deskriptif kualitatif, adapun yang dimaksud dengan desain penelitian deskriptif adalah salah satu bentuk penelitian yang memberikan penggambaran secara terperinci mengenai informasi bersifat ilmiah yang bersumber dari objek maupun subjek penelitian (Sanusi, 2014:13).

Penelitian ini menggunakan tingkat intervensi minimal. Sekaran \& Bougie (2017) menjelaskan tingkat intervensi minimal dalam suatu penelitian, peneliti hanya berwewenang sebagai pengumpul data tanpa melakukan pengaruh apapun terhadap hasil dalam penelitian. Sedangkan horizon waktu dalam penelitian ini menggunakan "Cross Sectional yaitu 
pengambilan data penelitian yang dilakukan hanya sekali dalam kurun satu waktu tertentu

\section{Objek Penelitian}

Penelitian ini dilakukan di Provinsi Aceh, adapun yang menjadi objek penelitian adalah Balai Diklat Keagamaan Provinsi Aceh yang baru berdiri di tahun 2013 dengan lokasi bangunan beralamat di PSBB MAN-1 Banda Aceh.

\section{Subjek Penelitian}

Responden atau partisipasi pada penelitian ini ialah Bidang Penyusun Anggaran dan Pelaporan yakni staf yang berhubungan lansung dan bekerja sebagai operator aplikasi SAIBA (Analis SAIBA) dan Kepala Balai Diklat Keagamaan Provinsi Aceh.

\section{Teknik Pengumpulan Data}

Teknik pengumpulan data yang diterapkan dalam penelitian berupa data primer dan data sekunder. Data primer melalui teknik wawancara, observasi dan dokumentasisedangkan data sekunder melalui catatan atau dokumen perusahaan, publikasi pemerintah, Web dan internet. Sedangkan aktifitas analisis data dalam penelitian ini meliputi reduksi data, penyajian data dan penarikan kesimpulan

\section{Hasil Penelitian dan Pembahasan \\ Pembahasan \\ Penerapan Akuntansi Berbasis Akrual}

Akuntansi berbasis akrual yang diterapkan dapat memberikan banyak keuntungan terhadap pengelolaan keuangan. Kompleksitas pelaporan keuangan tergambar dengan jelas. Basis akrual terbukti lebih unggul jika dibandingkan dengan yang sebelumnya berbasis kas. Laporan keuangan yang dihasilkan lebih akurat karena dapat memberikan penggambaran pencatatan secara lebih detail dimulai dari anggaran sampai pada pelaporan akhir.

Balai Diklat Keagamaan Provinsi Aceh melaksanakan akuntansi berbasis akrual sesuai dengan aturan pelaksanaan, akan tetapi ada beberapa permasalahan utama yang menyebabkan basis akrual belum bisa digolongkan dalam kategori efektif hal tersebut dikarenakan kemampuan SDM yang kurang dan belum sepenuhnya menguasai. Karena ini merupakan standar yang baru, dengan tingkat komponen yang sedikit lebih rumit. jadi perlu waktu yang lebih lama bagi staf untuk melakukan penyesuaian.

\section{Tantangan Penerapan Akuntansi Berbasis Akrual}

Keberhasilan Implementasi Akuntansi Berbasis Akrual ditentukan oleh besarnya dukungan dan komitmen dari seluruh pihak.terlebih lagi penerapan sudah diatur dalam Peraturan Pemerintah Nomor 71 Tahun 2010. Pimpinan mendukung setiap perubahan, dengan regulasi yang jelas diatur dalam baik dari segi prosedur, sistem, maupun kebijakan akuntansi dapat memunculkan sikap optimis bagi operator selaku pelaksana kebijakan untuk lebih memberikan kinerja yang maksimal sehingga keuntungan dari basis akrual dapat dirasakan.

Sumber Daya Manusia (SDM) yang berkualitas menjadi kunci sukses keberhasilan penerapan akuntansi berbasis akrual. (Azwan, 2015)menyatakan SDM yang berkualitas harus mampu menghasilkan laporan keuangan sesuai dengan aturan yang berlaku dengan pertimbangan integritas, kompetensi, loyalitas, reward, motivasi dan budaya organisasi.

Unit yang terkait dalam pelaksanaan akrual di Balai Diklat Keagamaan Provinsi Aceh adalah Subbagian Tata Usaha. Keterbatasan pemahaman mengenai pelaksanaan akuntansi berbasis akrual dari setiap staf disebabkan oleh sedikitnya staf yang berlatar pendidikan akuntansi. Akan tetapi untuk meminimalisir hal tersebut, langkah yang dilakukan dengan membuat sosialisasi dan pelatihan-pelatihan terkait SAIBA.

Periode awal tahun 2015 ada beberapa kali sosialisasi dan pelatihan, tetapi dua tahun terakhir hingga pada tahun 2018 sudah tidak ada lagi. Kegiatan Sosialisasi dijalankan sebagai wujud antisipasi kemungkinan terjadinya resistensi staf terhadap perubahan baru berbentuk SAIBA. Tujuan pelaksanaan agar para staf lebih mengenal akan keberadaan basis akrual sehingga kedatangan perubahan seperti ini tidak terasa asing dikalangan penyusun laporan keuangan.

\section{Kesiapan penerapan Sistem Akuntansi Instansi Berbasis Akrual berdasarkan Technology Acceptance Model}

TAM menjelaskan mengenai kemauan staf dalam mengadopsi SAIBA ditentukan oleh dua pertimbangan. Siregar (2011) menyatakan dua 
pertimbangan yang dapat mempengaruhi kemauan terhadap adopsi teknologi informasi diantaranya persepsi terhadap tingkat kemudahan dalam menggunakan teknologi dan persepsi akan manfaat dari suatu teknologi.

Berdasarkan wawancara dengan Bidang Penyusun Anggaran dan Pelaporan yang memaparkan bahwa Balai Diklat Keagamaan Provinsi Aceh terlalu mudah dalam menjalankan SAIBA bagi staf yang sudah menguasai. Akan tetapi hal tersebut tidak didorong oleh jumlah staf yang sangat sedikit menguasai. Kemudahan dalam menjalankan SAIBA akan menimbulkan mamfaat tersendiri. Manfaat yang didapat dari antara lain laporan keuangan lebih transaparan, serta dapat mencegah praktik Korupsi, Kolusi dan Nepotisme (KKN). Disamping itu juga dapat mempermudah dan mempercepat kerja staf.

\section{Kesimpulan, Keterbatasan, dan Saran Kesimpulan}

Berdasarkan hasil penelitian yang telah dikemukakan sebelumnya, dapat disimpulkan bahwa:

1) Implementasi Sistem Akuntansi Instansi Berbasis Akrual pada Balai Dilklat keagamaan Provinsi Aceh belum begitu efektif. Permasalahan utama terkait dengan kesiapan sumber daya manusia, banyak staf Balai Diklat Keagamaan Provinsi Aceh belum sepenuhnya paham terhadap Sistem Akuntansi Instansi Berbasis Akrual. Permasalahan timbul karena minimnya staf yang berlatar belakang pendidikan akuntansi di instansi tersebut. Walaupun pelaksanaan akuntansi berbasis akrual yang belum begitu efektif akan tetapi sudah membawa keuntungan dalam proses pelaporan. Pencatatan pelaporan keuangan pemerintah dapat tergambar secara jelas dan lebih akurat, dimulai dari sesi penganggaran sampai pada sesi pelaporan.

2) Tantangan pemerintah ditinjau dari segi komitmen pimpinan. Dalam hal ini Balai Diklat Keagamaan Provinsi Aceh mendukung perubahan akuntansi berbasis akrual karena regulasi yang jelas dan mutlak mengenai sistem, prosedur, dan kebijakan diatur dalam PP 71 Tahun 2010. Anggapan yang muncul untuk berkewajiban melaksanakan setiap perubahan yang terjadi tanpa mempunyai kemampuan untuk melalukan penolakan.

Adapun contoh baik dalam pelaksanaan SAIBA ialah pengelolaan anggaran di Balai Diklat Keagamaan Provinsi Aceh sudah sesuai dengan prosedur SAIBA. Sarana prasarana sistem akuntansi juga sudah memadai, aplikasi SAIBA yang komplek dengan penambahan 3 unsur laporan keuangan pokok.

3) Setiap perubahan baru dapat menimbulkan resistensi, maka oleh karena itu perlu dilakukan pembenahan kembali sebagai wujud antisipasi terjadinya penolakan dari setiap staf. Strategi yang dilakukan berupa Sosialisasi sekaligus pelatihan yang digencarkan pada awal tahun 2015 sampai sekarang.

4) Resistensi muncul atas dua pertimbangan yaitu kemudahan dan manfaat SAIBA. Tanggapan staf Balai Diklat Keagamaan Provinsi Aceh, mudah dalam menjalankan aplikasi SAIBA bagi yang sudah menguasai serta dapat mempermudah kinerja staf. Di sisi lain, ada manfaat yang didapat dari aplikasi SAIBA seperti laporan keuangan lebih transaparan dan akurat.

\section{Keterbatasan}

Penelitian ini mempunyai keterbatasanketerbatasan yang dapat dijadikan bahan pertimbangan bagi penelitian selanjutnya sehingga diperoleh hasil yang lebih baik lagi di masa yang akan datanga ntara lain:

1) Kekurangan responden untuk diwawancarai, dikarenakan hanya ada satu orang staf di Balai Diklat Keagamaan Provinsi Aceh yang mengerti seluk beluk SAIBA, jadi membuat peneliti kesulitan dalam pengumpulan data.

\section{Saran}

Berdasarkan kesimpulan dari hasil penelitian tersebut, maka timbul saran sebagai bahan pertimbangan dan pengevaluasian untuk memperbaiki penerapan Sistem Akuntansi Instansi Berbasis Akrual di Balai Diklat Keagamaan Provinsi Aceh. Tujuan dapat membawa dampak baik bagi pengelolaan pelaporan keuangan. Adapun saran-saran ialah sebagai berikut:

1. Memberikan sosialisasi beserta pelatihan secara berkala dan menyeluruh mengingat masih banyak 
staf yang tidak berlatar pendidikan akuntansi serta disamping itu akan tuntutan kebutuhan kualitas Sumber Daya Manusia yang berkompoten.

1. Fokus untuk lebih memperhatikan SDM dan melakukan perekrutan staf yang berpendidikan akuntansi serta mempunyai pemahaman terhadap Sistem Akuntansi Instansi Basis Akrual.

\section{Daftar Pustaka}

Azmi, A. H., \& Mohamed, N. (2014). Readiness of malaysian public sector employees in moving towards accrual accounting for improve accountability: the case of ministry of education (MOE). Social and Behavioral Sciences, 164, 106-111.

Azwan, M. M. (2015). Penerapan standar akuntansi pemerintahan berbasis akrual: sebuah analisis deskriptif. Makassar: Akuntansi, Ekonomi dan Bisnis Universitas Hasanuddin.

Direktorat Jenderal Perbendaharaan Kementerian Keuangan. (2015). Unduh aplikasi SAIBA. Melalui laman http://www.djpbn.kemenkeu.go.id /portal/id/unduh/aplikasi/431-aplikasi-saiba.html. Diakses 8 Mei 2018

Finansialku. (2017). Definisi akrual. Melalui laman https://www. finansialku.com/definisi-akrual/. Diakses 14 April 2018

Forum Dosen Akuntansi Sektor Publik. (2006). Standar akuntansi pemerintahan telaah kritis $P P$ Nomor 24 tahun 2005.Yogyakarta: Bpfeyogyakarta.

Harun. (2009). Reformasi akuntansi dan manajemen sektor publik di Indonesia. Jakarta: Salemba Empat.

Herwiyanti, E., Sukirman, \& Aziz, F. S. (2017). Analisis implementasi akuntansi berbasis akrual pada Inspektorat Jenderal Kementerian Keuangan. Jurnal Akuntansi Dan Keuangan, 19(1), 13-23.

Kementerian Keuangan Republik Indonesia. Program Percepatan Akuntanbilitas Pemerintah Pusat. (2014). Proses Bisnis SAIBA. Melalui laman https://anzdoc.com/ modul- overview- prosesbisnis- saiba- program-percepatan-akunta.html. Diakses 8 Mei 2018
KeuanganLSM. (2013). Apa arti dari prinsip yang berlaku umum di Indonesia itu. Melalui laman http://keuanganlsm.com/apa- arti- dari- prinsipakuntansi- yang- berlaku- umum-di- indonesiaitu/. Diakses 9 April 2018

Kompasiana (2016). Satu tahun Indonesia bersama akrual basis. Melalui laman https://www.kompasiana.com/fikrireza/satu-

tahun-indonesia-bersama- akrualbasis_5736cd6fb47e61340b1a370b. Diakses 26 Maret 2018

Kurniawan, Y., \& Yuswanto. (2016). Pengembangan program sistem informasi akuntansi berbasis akrual sesuai dengan standar akuntansi pemerintahan (SAP). Jurnal Nasional Pendidikan Teknik Informatika, 5(17), 40-48.

Lestari, D. (2017). Analisis penerimaan aplikasi sistem akuntansi instansi berbasis akrual (SAIBA) dengan menggunakan pendekatan technology acceptance model (TAM) pada satuan kerja kementerian agama mitra layanan KPPN medan II. Medan: Magister akuntansi, Ekonomi dan bisnis Universitas Sumatera Utara.

Mehrolhassani, M. H., Khayatzadeh-Mahani, A., \& Emami, M. (2014). Implementation status of accrual accounting system in health sector. Global Journal of Health Science, 7(1).

Moleong, L. (2005). Metodologi penelitian kualitatif. Bandung: PT Remaja Rosdakarya.

Najati, I., Pituringsih, E., \& Animah. (2016). Implementasi akuntansi berbasis akrual : pengujian determinan dan implikasinya terhadap kualitas laporan keuangan kementerian/lembaga. Jurnal Akuntansi Universitas Jember, 14(1), 118.

Nordiawan, D., \& Hertianti, A. (2010). Akuntansi sektor publik. Jakarta: Salemba Empat.

Noviyanti. (2016). Mengukur kesukssan sistem akuntansi instansi basis akrual (SAIBA) menggunakan model DeLone \& McLean. Jurnal Tata Kelola \& Akuntabilitas Keuangan Negara, 2(2), 151-173.

republikPriyono, N. (2012). Perkembangan akuntansi pemerintahan di Indonesia periode sebelum reformasi sampai dengan pasca reformasi. Vol 37, 1-15.

Republik Indonesia. Peraturan Menteri Keuangan No. 213/PMK.05/2013 Tentang Sistem Akuntansi dan 
Pelaporan Keuangan Pemerintah Pusat.

Republik Indonesia. Peraturan Menteri Keuangan No.

270/PMK.05/2014 Tentang Standar Akuntansi

Pemerintahan Berbasis Akrual pada Pemerintah

Pusat.

Republik Indonesia. Peraturan Pemerintah No. 56

Tahun 2005 Tentang Sistem Informasi Keuangan

Daerah.

Republik Indonesia. Peraturan Pemerintah No 71

Tahun 2010 Tentang Standar Akuntansi

Pemerintahan.

Republik Indonesia. Undang-undang No. 17 Tahun 2003 Tentang Keuangan Negara.

Rosalia., \& Kawedar, W (2017) Implementasi pelaporan keuangan berbasis akrual pada perguruan tinggi negeri badan hukum: analasis deskriptif kualitatif. Diponegoro journal of accounting. 6 (3), 1-12.

Sanusi, A. (2014). Metodologi penelitian bisnis. Jakarta: Salemba Empat.

Saputra, F. (2015). Kedudukan Bendahara Pasca Berlakunya Undang-Undang Nomor 1 Tahun 2004 Tentang Perbendaharaan Negara. Yuridika, 30(1), 267-280.

Satker (2016). Pengantar SAIBA. Melalui laman. http://satker.com/pengantar-saiba.html. Diakses 10 Mei 2018

Sari, Y. P., Hertika, \& Mahmudah, N. (2017). Evaluasi penerapan sistem akuntansi akrual: studi kasus dibadan layanan umum daerah RUSD kardinah kota tegal. Jurnal AKSI (Akuntansi Dan Sistem Informasi), 1, 18-28.

Sekaran, U., \& Bougie, R. (2017). Metode penelitian untuk bisnis (pendekatan pengembangankeahlian). Jakarta: Salemba Empat.

Siregar, K. R. (2011). Kajian mengenai penerimaan teknologi dan informasi menggunakan technology accaptance model ( TAM ). Rekayasa, 4(1).

Zawitri, S., Kurniasih, N., \& Kartikawati, T. S. (2015). Penerapan sistem akuntansi instansi berbasis akrual sebagai implementasi PP No . 71 tahun 2010 pada Politeknik Negeri Pontianak. Jurnal Ekonomi Bisnis Dan Kewirausahaan, 4(1), 2444. 